University of Nebraska - Lincoln

DigitalCommons@University of Nebraska - Lincoln

Agronomy \& Horticulture -- Faculty Publications

Agronomy and Horticulture Department

2013

Soil sorptivity enhancement with crop residue accumulation in semiarid dryland no-till agroecosystems

T.M. Shaver

University of Nebraska-Lincoln, tshaver2@unl.edu

G. A. Peterson

Colorado State University, gary.peterson@colostate.edu

Laj R. Ahuja

USDA-ARS, laj.ahuja@ars.usda.gov

D.G. Westfall

Colorado State University

Follow this and additional works at: https://digitalcommons.unl.edu/agronomyfacpub

Part of the Agricultural Science Commons, Agriculture Commons, Agronomy and Crop Sciences Commons, Botany Commons, Horticulture Commons, Other Plant Sciences Commons, and the Plant Biology Commons

Shaver, T.M.; Peterson, G. A.; Ahuja, Laj R.; and Westfall, D.G., "Soil sorptivity enhancement with crop residue accumulation in semiarid dryland no-till agroecosystems" (2013). Agronomy \& Horticulture -Faculty Publications. 681.

https://digitalcommons.unl.edu/agronomyfacpub/681

This Article is brought to you for free and open access by the Agronomy and Horticulture Department at DigitalCommons@University of Nebraska - Lincoln. It has been accepted for inclusion in Agronomy \& Horticulture -Faculty Publications by an authorized administrator of DigitalCommons@University of Nebraska - Lincoln. 


\title{
Soil sorptivity enhancement with crop residue accumulation in semiarid dryland no-till agroecosystems
}

\author{
T.M. Shaver ${ }^{\mathrm{a}, *}$, G.A. Peterson ${ }^{\mathrm{b}}$, L.R. Ahuja ${ }^{\mathrm{c}}$, D.G. Westfall ${ }^{\mathrm{b}}$ \\ a Department of Agronomy and Horticulture, University of Nebraska-Lincoln, WCREC, 402 W State Farm Rd., North Platte NE 69101, USA \\ b Department of Soil and Crop Sciences, Colorado State University, Fort Collins CO 80523, USA \\ c Agricultural Systems Research Unit, USDA-ARS, Fort Collins CO 80526, USA
}

\section{A R T I C L E I N F O}

\section{Article history:}

Received 22 July 2011

Received in revised form 25 June 2012

Accepted 13 August 2012

Available online 17 November 2012

Keywords:

Soil sorptivity

Crop residue

Soil physical properties

\begin{abstract}
A B S T R A C T
Water capture and precipitation use efficiency are of great importance in dryland cropping systems because the world's dependence on food produced in dryland areas continues to increase. Growing season evapotranspiration potential greatly exceeds growing season precipitation rates in dryland areas, creating a water deficit for crops. Management practices that positively impact soil physical properties increase the potential for soils to capture water. One way to assess the ability of soils to capture water is through the measurement of sorptivity. Sorptivity is defined as the cumulative infiltration proportionality constant and is governed by surface soil physical properties such as texture, degree of aggregation and aggregate stability. A study was conducted to determine how crop residue accumulation after 12 years of no-till management affects surface soil sorptivity under semi-arid dryland conditions and how sorptivity is related to surface soil physical properties known to be related to crop residue accumulation. Surface soil sorptivity, bulk density, porosity (total and effective) and aggregation measurements were made across cropping systems and soil positions representing a wide gradient of crop residue accumulation at 3 sites in eastern Colorado. Results show that increasing crop residue accumulation will have the indirect effect of increased sorptivity via improvements in soil aggregation, bulk density, and porosity that are conducive to water infiltration. Management practices that result in greater amounts of crop residue returned to the soil system lead to beneficial soil physical properties that increase water sorptivity, greatly reducing the potential for runoff and erosion, and thereby increase the precipitation use efficiency of the system.
\end{abstract}

(C) 2012 Elsevier B.V. All rights reserved.

\section{Introduction}

Improving precipitation use efficiency in the world's dryland agroecosystems is more critical now than ever because the world's dependence on food produced in dryland areas continues to increase. Unger et al. (2006) expressed this global challenge clearly and succinctly:

"During the next several decades, dryland agriculture will play an increasingly important role in our efforts to maintain global food security. How, one must ask, are they to feed those populations when irrigation cannot keep pace with water demand? To meet this challenge, dryland cropping systems in developed and developing countries alike must use precipitation as efficiently as possible for food production. To realize increased efficiency requires an understanding of how crop production is related to such determining factors as precipitation and evaporative demand, water capture, water retention, and crop management."

\footnotetext{
* Corresponding author. Tel.: +1 308696 6714; fax: +1 3086966780. E-mail address: tshaver2@unl.edu (T.M. Shaver).
}

Obviously water availability is essential for plant establishment and successful production in all agroecosystems, but especially so in dryland systems. Dryland agroecosystems characteristically have annual growing season evapotranspiration potentials that greatly exceed average growing season precipitation, which creates a water deficit for the crops (Peterson et al., 1993; Shaver et al., 2002). Precipitation events occur sporadically and are often short in duration and high in intensity resulting in lower and less stable plant yields with more risk to producers. Successful crop production in dryland agroecosystems depends heavily on capturing and storing adequate soil water to sustain the crop until the next precipitation event. Thus, the focal point of the soil management practices in dryland agroecosystems is water conservation and in particular rapid water capture (Peterson et al., 2012).

Management practices that positively affect soil physical properties related to soil water capture increase the potential for soils to infiltrate water below the surface thereby decreasing the potential for water loss from runoff and surface evaporation. The physical properties of the uppermost surface soil layer are most critical because they represent the initial soil-precipitation interface. Crop residue retention and tillage management have major impacts on surface soil physical properties 
that are of importance to water capture and infiltration. Practices that cause minimal soil disturbance and leave greater quantities of crop residue on the soil surface have the potential to decrease soil bulk density, increase porosity, increase aggregation, create macropores, and therefore, increase water capture and retention in the soil over time thereby increasing the precipitation use efficiency of semiarid dryland cropping systems.

Previous studies have shown how crop residue influences soil physical properties related to water infiltration. Shaver et al. (2002) found that surface soil (top $2.5 \mathrm{~cm}$ ) bulk density, porosity (total and effective), and macroaggregation were directly related to crop residue accumulation over a 12 year period in western Great Plains dryland cropping systems. Greater quantities of crop residue resulted in decreased bulk density, increased porosity and increased aggregation. Dao (1996) found that increased amounts of residue decreased bulk density in the surface 0 to $5 \mathrm{~cm}$ of soil. Blanco-Canqui et al. (2006) observed that corn stover removal from no-till systems reduced aggregate stability by up to $300 \%$ within 1 year of removal and several studies have positively correlated aggregate stability with soil organic matter concentration (Blanco-Canqui et al., 2006; Bossuyt et al., 2005; Rhoton et al., 2002). Blanco-Canqui and Lal (2009) also reported that total porosity increased with rate of corn stover mulch in sloping silt loam and flat clay loam Ohio soils. These studies collectively illustrate the relationship of crop residue and associated soil organic matter with soil physical properties important for water capture in soil.

Numerous studies have also been conducted to determine the effects of crop residue on water infiltration. Dao (1993) found (using double ring infiltrometers) that in a no-till soil with surface residues, ponded infiltration was increased when compared with traditional tillage resulting in bare soil. Blanco-Canqui and Lal (2007) reported that soil water storage from rains decreased with increased stover removal in Ohio soils under no-till management. They reported that stover removal increased soil surface sealing, crusting, and consolidation which was the primary cause of reduction in water infiltration rate (Blanco-Canqui and Lal, 2009). These studies show that as crop residue is removed, water infiltration rates decrease, illustrating the importance of crop residue for water capture.

Another means of assessing a soil's ability to rapidly capture water is through a sorptivity measurement. Sorptivity is defined as the cumulative infiltration proportionality constant (Philip, 1957) and is governed by surface soil physical properties such as texture, degree of aggregation and aggregate stability (Taylor and Ashcroft, 1972). Some macropores (decayed root channels, worm holes) created in a no-till soil may also increase ponded water sorptivity. Sorptivity is the dominant parameter governing the early stages of infiltration, which is of great importance to water capture in semiarid dryland systems due to the large potential for water loss from runoff or evaporation (Shaver et al., 2003). Increased crop residue additions have the potential to increase soil organic matter which in turn strengthens soil structure and soil aggregation, thereby increasing potential sorptivity and water capture. Thus, we used sorptivity in our study to determine the effects of crop residue on potential water capture.

Our objectives were the following:

1. To relate crop residue accumulation over a 12 year period to surface soil sorptivity under semiarid dryland no-till conditions.

2. To relate sorptivity to surface soil $(2.5 \mathrm{~cm}$ ) physical properties (bulk density, total porosity, effective porosity, and macroaggregation).

We hypothesized that management practices and locations that produced and returned the highest quantities of crop residue to the soil surface would result in the highest (fastest) sorptivity levels. We also hypothesized that higher sorptivity levels would be associated with decreased bulk density, increased porosity (total and effective), and increased aggregation. Previous work in dryland water conservation in the Great Plains has concentrated on water capture differences created by different management practices such as tillage. There are few papers published comparing water capture across different crop residue accumulation regimes related to cropping system. Additionally our study was unique in that it examined sorptivity in relation to soil physical properties that have been proven to be directly related to crop residue accumulation over time. This affords us the opportunity to examine the direct and indirect relationships of sorptivity with crop residue accumulation and soil physical properties and gauge the importance of crop residue in terms of water capture under semiarid dryland no-till conditions.

\section{Materials and methods}

\subsection{Sites}

Sites, located near Sterling, Stratton, and Walsh, in eastern Colorado were sampled in the summer of 1998 after 12 years of dryland no-till management. Sorptivity measurements were also collected at this time. These sites represent an evaporation gradient from the northern site (Sterling) to the southern site (Walsh) (Table 1). Sterling experiences the least amount of open pan evaporation with $1600 \mathrm{~mm}$ during the cropping season (May-September). Walsh experiences the greatest with $1975 \mathrm{~mm}$, and Stratton is intermediate with $1725 \mathrm{~mm}$ (Peterson et al., 1993, 1999). Average annual precipitation ranges from $440 \mathrm{~mm} \mathrm{yr}^{-1}$ in northeastern Colorado to $395 \mathrm{~mm} \mathrm{yr}^{-1}$ in southeastern Colorado (Peterson et al., 1993). All sites had been managed with tillage in either wheat (Triticum aestivum) fallow or sorghum (Sorghum bicolor) fallow systems for more than 50 years until no-till management was established in 1985. Each site is located on a soil catena consisting of a summit slope, side slope, and toe slope positions. For this study only the summit and toe slopes of each site were sampled. Site coordinates and soil classifications are listed in Table 1.

Each site had three distinct cropping systems in place over the 12 year period. These cropping systems ranged from low intensity (1 crop in 2 years) to medium intensity ( 2 crops in 3 years) to high intensity ( 3 crops in 3 years). The low intensity cropping system was wheat fallow (WF), the medium intensity system was wheat corn (Zea mays) fallow (WCF), and the high intensity system was continuous cropping (CC) (Table 2 contains cropping history of each site). At Walsh, sorghum is used in the three-year system instead of corn due to the high evaporation potential in that area (Peterson et al., 1993). Each site had 2 replications of each cropping system and each replication had each phase of every cropping system each year. Cropping systems were set up as strips that go along each slope on the soil catena. Each strip was 6.1 meters wide and varied by site in length from 225 to 325 meters.

\subsection{Residue accumulation}

Residue was collected within each cropping system at each soil position (summit and toeslope) on an annual basis from 1986 to 1997 using a 1 meter quadrant. Cumulative residue placement by slope position and cropping system over the 12 year period was then calculated and is reported in Shaver et al. (2002). More intensive cropping systems

Table 1

Research site location (latitude and longitude) and soil classification (summit and toe slope).

\begin{tabular}{|c|c|c|c|c|}
\hline \multirow[t]{2}{*}{ Site } & \multirow[t]{2}{*}{ Latitude } & \multirow[t]{2}{*}{ Longitude } & \multicolumn{2}{|l|}{ Soil Classification } \\
\hline & & & Summit Slope & Toe Slope \\
\hline Sterling & $40.37 \mathrm{~N}$ & $103.13 \mathrm{~W}$ & $\begin{array}{l}\text { Fine, montmorillonitic, } \\
\text { mesic, Aridic Paleustoll }\end{array}$ & $\begin{array}{l}\text { Fine, montmorillonitic, } \\
\text { mesic, Pachic Argiustoll }\end{array}$ \\
\hline Stratton & $39.18 \mathrm{~N}$ & $102.26 \mathrm{~W}$ & $\begin{array}{l}\text { Fine-silty, mixed, mesic, } \\
\text { Aridic Argiustoll }\end{array}$ & $\begin{array}{l}\text { Fine-silty, mixed, } \\
\text { mesic, Pachic Argiustoll }\end{array}$ \\
\hline Walsh & $37.23 \mathrm{~N}$ & $102.17 \mathrm{~W}$ & $\begin{array}{l}\text { Fine, montmorillonitic, } \\
\text { mesic, Ustollic } \\
\text { Haplargid }\end{array}$ & $\begin{array}{l}\text { Fine, montmorillonitic, } \\
\text { mesic, Ustollic } \\
\text { Paleargid }\end{array}$ \\
\hline
\end{tabular}


Table 2

Continuous cropping history from 1985 to 1998 at Sterling, Stratton, and Walsh Colorado.

\begin{tabular}{llll}
\hline \multirow{2}{*}{ Year } & Sterling & Stratton & Walsh \\
\cline { 2 - 2 } & Crop & & \\
\hline 1985 & Wheat & Fallow & Sorghum \\
1986 & Wheat & Wheat & Sorghum \\
1987 & Corn & Sorghum & Proso Millet \\
1988 & Corn & Sorghum & Sudex \\
1989 & Attempted hay millet & Attempted hay millet & Sorghum \\
1990 & Wheat & Wheat & Attempted hay millet \\
1991 & Corn & Corn & Wheat \\
1992 & Hay millet & Hay millet & Corn \\
1993 & Corn & Corn & Fallow \\
1994 & Sunflower & Sunflower & Wheat \\
1995 & Wheat & Wheat & Wheat \\
1996 & Corn & Corn & Fallow \\
1997 & Hay millet & Hay millet & Corn \\
1998 & Wheat & Wheat & Sorghum \\
\hline & & & \\
& & & \\
\hline
\end{tabular}

in lower evaporation environments placed larger amounts of crop residue on the soil surface over the 12 year period, and toe slope positions acquired more residue than the summit slope (Shaver et al., 2002). The three site locations, three cropping systems, and two slope positions resulted in a wide gradient of crop residue accumulation that directly affected surface soil physical properties such as bulk density, porosity (total and effective), and aggregation (Shaver et al., 2002).

\subsection{Sorptivity}

Sorptivity measurements were collected within each cropping system at the summit and toe slope positions across all replications at all three site locations. Sorptivity measurements were made using methods reported by Smith (1999), with one alteration. Only the complete infiltration time was recorded; the $50 \%$ infiltration measurement was not taken as this measurement is subjective and prone to error. Rings $10.5 \mathrm{~cm}$ in height and $9.8 \mathrm{~cm}$ in diameter were pushed into the soil surface between plant rows by hand. Any debris or plant material that could be removed without disturbing the surface was removed. If the surface cracked when the ring was placed in the soil, the ring was removed and placed in another position. Each ring was pushed into the soil to a depth of approximately $2.5 \mathrm{~cm}$ to prevent lateral flow. Thirty-nine measurements were taken at each soil position in an attempt to account for spatial variability.

Water was poured into the ring to a depth of $1 \mathrm{~cm}(75 \mathrm{ml})$. The water was poured along the inside wall of the ring to dissipate energy that could have disrupted the soil surface. A stopwatch was used to measure the time it took for the water to infiltrate. Sorptivity was then calculated using the following equation (Smith, 1999):

$$
\text { sorptivity }(S)=1 / \sqrt{t} \text { where : } 1=\text { head of water }(\mathrm{cm})
$$$$
t=\text { time (seconds) }
$$

Four random soil samples were taken at each soil position to determine the initial soil water content on the day the sorptivity measurements were collected. Measured sorptivities were adjusted to correspond to the average initial water deficit $\left(\ominus_{s}-\ominus_{i}\right)$ of all positions for comparisons within site. Here $\ominus_{s}$ equals the porosity estimated from bulk density and $\ominus_{\mathrm{i}}$ is the initial soil water content. The relationship $S^{2}=2 G K_{\mathrm{s}}\left(\ominus_{\mathrm{s}}-\ominus_{\mathrm{i}}\right)$ (Eq. [1] of Smith, 1999) was used for this purpose, with parameters $G$ (capillary length scale) and $K_{\mathrm{s}}$ (saturated conductivity) assumed constant with a given cropping system and slope position. Thus, Si measured at initial $\ominus_{\mathrm{i}}$ was adjusted to Si mean at $\ominus_{\mathrm{i}}$ mean as $\operatorname{Si}$ mean $=\operatorname{Si} \times \operatorname{sqrt}\left(\left(\ominus_{\mathrm{s}}-\ominus_{\mathrm{i}, \text { mean }}\right) /\left(\ominus_{\mathrm{s}}-\ominus_{\mathrm{i}}\right)\right)$.

\subsection{Bulk density, total and effective porosity}

Bulk density, total porosity, and effective porosity were determined on the surface $2.5 \mathrm{~cm}$ of soil. Bulk density was determined using a modified version of the core method (Shaver et al., 2002). Total porosity was calculated using the equation and relationships developed by Danielson and Sutherland (1986). Effective porosity was determined using methods developed by Ahuja et al. (1984), and was defined as total porosity minus volumetric water content at $-10 \mathrm{kPa}$ suction (Shaver et al., 2002).

\subsection{Aggregates}

Water-stable aggregates were determined following procedures developed by Kemper and Rosenau (1986). Fifty-gram surface soil samples (top $2.5 \mathrm{~cm}$ ) were placed in a stack of sieves of progressively smaller size attached to a dipping mechanism. The sieves were cycled through a column of water for 10 minutes ( 30 times per minute, $3.8 \mathrm{~cm}$ stroke) yielding a delineated size fraction of water stable aggregates. The percentage of aggregates as a fraction of the total soil sample was then calculated. Aggregates were then fractionated into macro $(>0.25 \mathrm{~mm})$ and micro $(<0.25 \mathrm{~mm})$ categories. All aggregate fractions were corrected for sand content by dispersion with Na-hexametaphosphate (HMP).

\subsection{Aggregate organic carbon}

Aggregate organic carbon (C) concentration was determined for each aggregate fraction. The separated aggregates from each treatment were randomly sampled and analyzed for total C (TC) in a LECO CHN 1000 Auto-Analyzer. Total C was corrected for inorganic C (IC), by using a modified pressure calcimeter method (Sherrod et al., 2002).

\subsection{Statistical analysis}

All statistical analysis was performed using the Statistical Analysis System (SAS Institute, 2011). All regression relationships were performed using the Regression Procedure and all means calculations were performed using the Means Procedure. The stepwise multiple regression was performed using the MaxR Stepwise Procedure.

\section{Results and discussion}

\subsection{Crop residue}

Previous research has shown that cropping systems and soil positions that produce and return higher quantities of crop residue to the soil surface decrease surface soil bulk density while increasing porosity (total and effective) and soil aggregation (Shaver et al., 2002). Therefore, it is reasonable to hypothesize that crop residue accumulation would also increase soil sorptivity. Increased porosity should lead to an increased absorption of water into the soil. Our data indicate a trend for increased sorptivity with increased crop residue accumulation (Fig. 1), which supports our hypothesis. However, the sorptivity data are highly variable, and subsequently the $r^{2}$ for this relationship was only 0.50 . Obviously residue accumulation alone was not highly related to soil sorptivity. The variability in sorptivity can be explained by spatial variability of residue cover and other factors that also affect water absorption and movement into the soil, such as soil texture. However, when the relationship of sorptivity with soil physical properties such as bulk density, porosity and aggregation (properties affected by soil texture and crop residue accumulation) is examined, surface soil sorptivity has an important indirect relationship with crop residue accumulation. The following sections will document these relationships. 


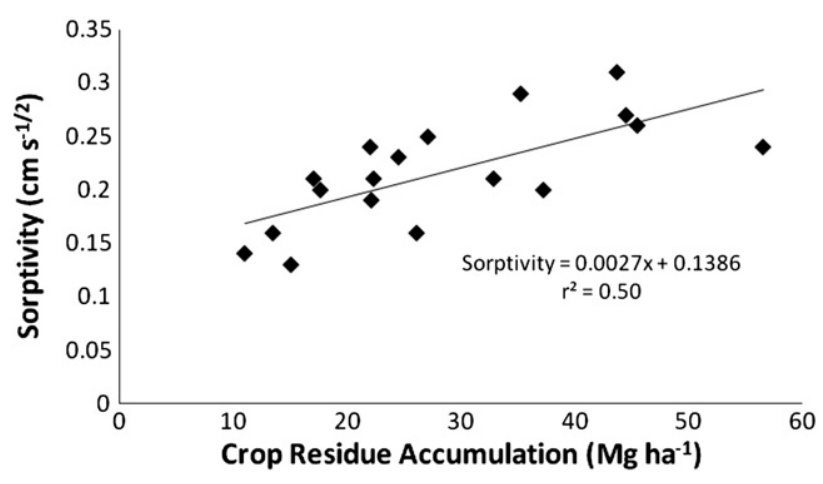

Fig. 1. Sorptivity as affected by crop residue accumulation over a period of 12 years under dryland no-till management.

\subsection{Bulk density and porosity}

As crop residue accumulation increases, surface soil bulk density decreases (Shaver et al., 2002). Total porosity is inversely related to bulk density, and increases with decreased bulk density. Our hypothesis that sorptivity is directly related to surface soil bulk density (and therefore total porosity) is supported by the data in Figs. 2 (bulk density) and 3 (total porosity). As surface soil bulk density decreases (and total porosity increases) sorptivity increases. Seventy seven percent of the variability in sorptivity $\left(r^{2}=0.77\right)$ can be explained by either bulk density or porosity. Bulk density alters sorptivity and water infiltration because it is directly related to soil porosity. Systems that produce more crop residue reduce surface bulk density because under no-till conditions the residue accumulates in the surface soil layer. Accumulation in the surface soil layer does three things: 1) residue is lighter than mineral matter, and therefore bulk density decreases by dilution; 2) residue decomposition products promote more aggregation and thus reduces bulk density; and 3 ) the root activity in the surface increases because of the improved water conditions and the increased root activity in turn favors aggregation. All of these factors increase potential water infiltration and clearly demonstrate that sorptivity is directly related to bulk density (and total porosity) and is therefore indirectly related to crop residue accumulation.

Effective porosity is a calculated value based on air-filled porosity at $-10 \mathrm{kPa}$ water potential. The effective porosity represents larger pores that absorb and primarily conduct water, whereas the smaller pores absorb and essentially hold water. The effective porosity is related to $K_{\mathrm{s}}$ in the equation $S^{2}=2 G K_{\mathrm{s}}\left(\ominus_{\mathrm{s}}-\ominus_{\mathrm{i}}\right)$. Hence the sorptivity should also be related to effective porosity. While the results show that there is a positive relationship between sorptivity and effective porosity the variability in the data was large; only $52 \%\left(r^{2}=0.52\right)$ of the variability in sorptivity was explained by effective porosity (Fig. 4). This suggests that the absorption of water into all pores dominates in early stages of infiltration.

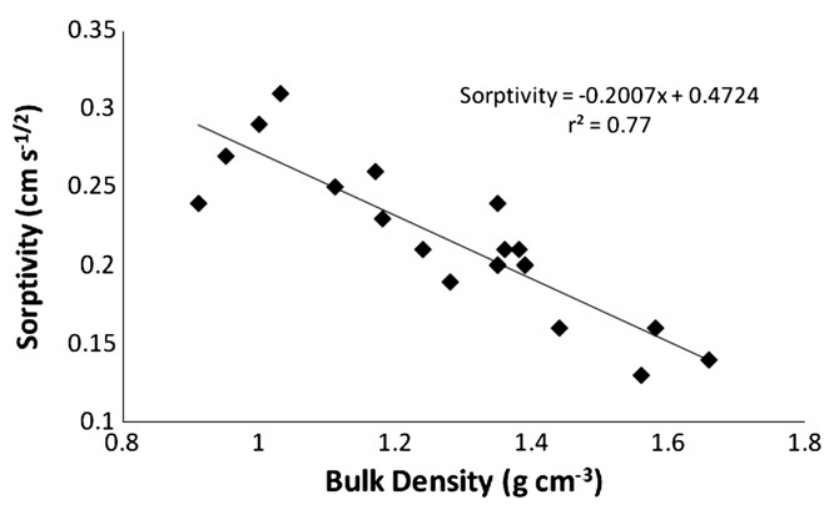

Fig. 2. Sorptivity as affected by surface soil bulk density after 12 years of dryland no-till management.

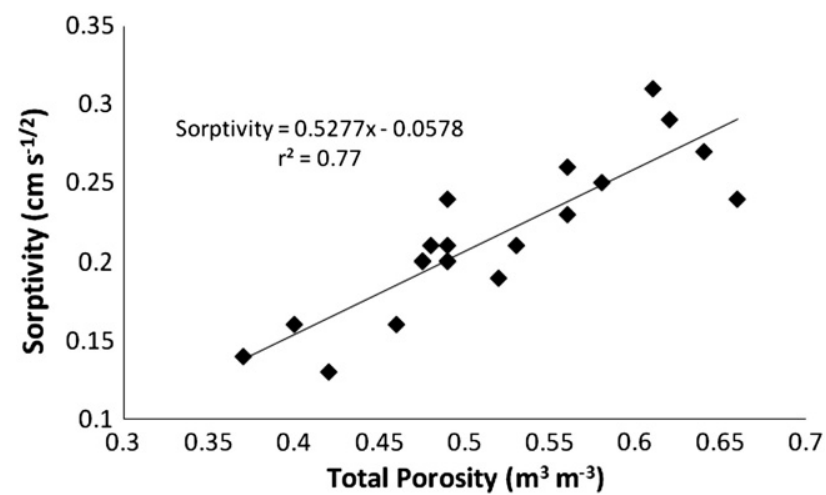

Fig. 3. Sorptivity as affected by surface soil total porosity after 12 years of dryland no-till management.

\subsection{Aggregation}

Aggregation is a soil physical property long recognized as critical to maintaining water infiltration, control of wind and water erosion, and ultimately crop yields. As aggregates form they consolidate soil particles reducing bulk density and increasing total porosity allowing greater potential for water to move into the soil. Therefore, we hypothesized that as aggregation increased, so should sorptivity. Data presented in Fig. 5 support this hypothesis; as macroaggregation increased, sorptivity increased (Fig. 5). Macroaggregation explained $73 \%\left(r^{2}=0.73\right)$ of the variability observed in sorptivity measurements.

Macroaggregation is affected by many factors, but most importantly by organic matter (from crop residue and roots) and soil texture. Macroaggregate stability has been correlated with sterols, lipids, organic carbon and many other organic matter characteristics (Monreal et al., 1995) that bind and stabilize macroaggregates. Thus, macroaggregates increase as these binding agents increase with increased crop residue accumulation. Our macroaggregate and sorptivity data indicate that increased macroaggregation leads to increased sorptivity, again demonstrating that crop residue accumulation and sorptivity are highly related, although indirectly by modifying soil aggregation, bulk density, and total porosity resulting in favorable conditions for water infiltration into the soil.

\subsection{Macroaggregate organic carbon content}

As mentioned above macroaggregate formation and stability are correlated with sterols, lipids, organic carbon and many other organic matter characteristics that bind and stabilize the macroaggregates (Monreal et al., 1995). Shaver et al. (2003) demonstrated that soil macroaggregate quantity and macroaggregate organic $C$ content are highly related $\left(r^{2}=0.89\right)$, showing that crop residue additions are

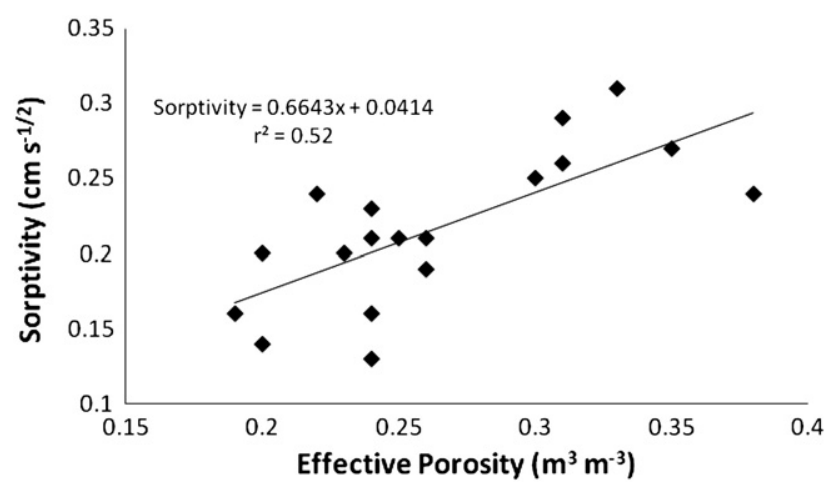

Fig. 4. Sorptivity as affected by surface soil effective porosity after 12 years of dryland no-till management. 


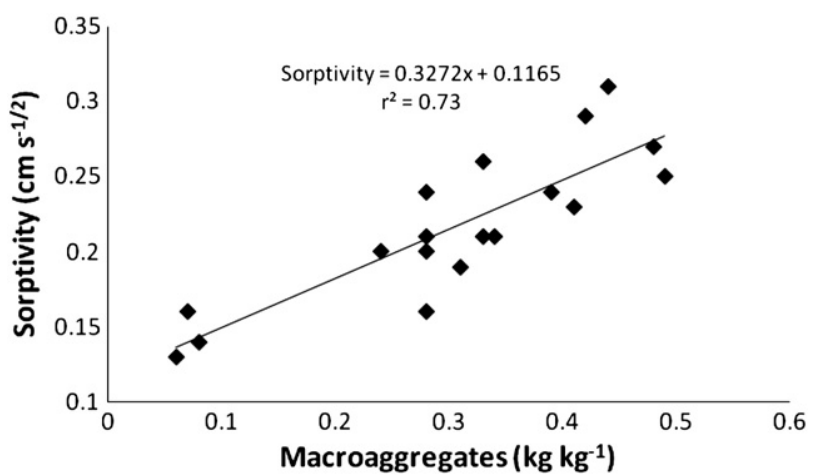

Fig. 5. Sorptivity as affected by surface soil macroaggregates after 12 years of dryland no-till management.

important in the formation of macroaggregates. Therefore, we hypothesized that increased macroaggregate organic $C$ content would lead to greater sorptivity. Note in Fig. 6 that macroaggregate organic C content explained $85 \%\left(r^{2}=0.85\right)$ of the variability observed in sorptivity. This relationship tended to be stronger than that of soil macroaggregate content with sorptivity $\left(r^{2}=0.73\right)$ and demonstrates how closely related macroaggregate formation and macroaggregate organic $\mathrm{C}$ content are. Increased organic $\mathrm{C}$ content led to increased macroaggregation and therefore increased soil porosity and sorptivity.

\subsection{Multiple regression}

We co-evaluated the relationship of total porosity, macroaggregation and macroaggregate organic $\mathrm{C}$ content (the three soil physical properties found to be most associated with sorptivity) with sorptivity using a stepwise multiple regression. The three variable combination yielded a significant $R^{2}$ value $\left(R^{2}=0.86\right)$, which was basically the same as the relationship between sorptivity and macroaggregate organic $C$ content $\left(r^{2}=0.85\right)$. This indicates that the organic $C$ content of the macroaggregates is the key factor in the relationship of sorptivity and physical properties. Obviously cropping systems that produce more biomass that is returned to the soil surface are highly likely to have positive effects on soil sorptivity.

\section{Conclusions}

We hypothesized that crop residue accumulation would increase sorptivity because crop residue is known to positively impact soil physical properties beneficial to water absorption and infiltration. While the direct relationship of sorptivity with crop residue accumulation was weak, other soil physical properties such as bulk density, total porosity and macroaggregation were highly related to sorptivity. Sorptivity increased with decreasing bulk density and increased with increasing total porosity and macroaggregation. Increasing cropping intensity in our systems produced and returned higher quantities of crop residue to the soil surface which decreased bulk density and increased total porosity and macroaggregation. Our data clearly show that increasing crop residue accumulation will increase sorptivity indirectly via improvements in soil physical properties that are conducive to water infiltration. All management practices that result in greater amounts of crop residue returned to the soil system lead to beneficial soil physical properties that increase water sorptivity, greatly reducing the potential for runoff and erosion, and thereby increase the precipitation use efficiency of the system.

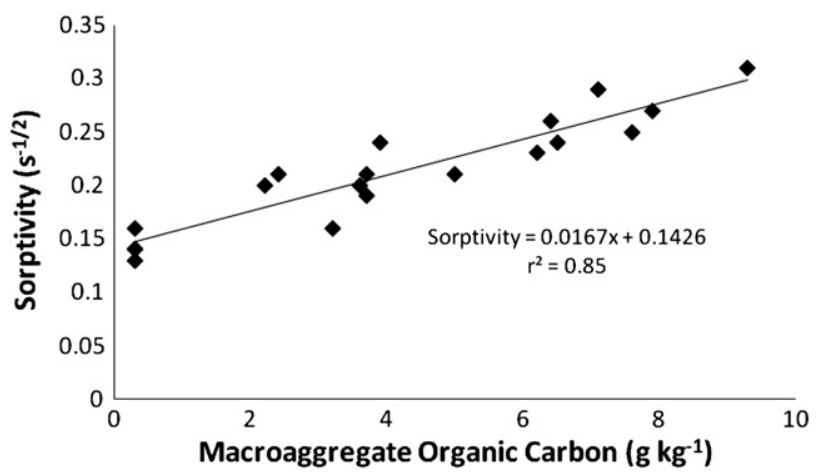

Fig. 6. Sorptivity as affected by surface soil macroaggregate organic carbon content after 12 years of dryland no-till management.

\section{References}

Ahuja, L.R., Naney, R.E., Green, R.E., Nielsen, D.R., 1984. Macroporosity to characterize spatial variability of hydraulic conductivity and effects of land management. Soil Science Society of America Journal 48, 699-702.

Blanco-Canqui, H., Lal, R., 2007. Soil and crop response to harvesting corn residues for biofuel production. Geoderma 145, 335-346.

Blanco-Canqui, H., Lal, R., 2009. Crop residue removal impacts on soil productivity and environmental quality. Critical Reviews in Plant Sciences 28, 139-163.

Blanco-Canqui, H., Lal, R., Post, W.M., Izaurralde, R.C., Owens, L.B., 2006. Soil structural parameters and organic carbon in no-till corn with variable stover retention rates. Soil Science 171, 468-482.

Bossuyt, H., Six, J., Hendrix, P.F., 2005. Protection of soil carbon by microaggregates with earthworm casts. Soil Biology and Biochemistry 37, 251-258.

Danielson, R.E. Sutherland, P.L. 1986. Porosity, In: Klute, A. (Ed.), Methods of soil analysis Part 1. Physical and mineralogical methods, Second edition. : Agronomy Monograph, 9. American Society of Agronomy, Madison WI, pp. 443-461.

Dao, T.H., 1993. Tillage and winter wheat residue management effects of water infiltration and storage. Soil Science Society of America Journal 57, 1586-1595.

Dao, T.H., 1996. Tillage system and crop residue effects on surface compaction of a Paleustoll. Agronomy Journal 88, 141-148.

Kemper, W.D., Rosenau, R.C., 1986. Aggregate stability and size distribution, In: Klute, A (Ed.), Method of soil analysis, Part 1, Physical and mineralogical methods, Second edition. : Agronomy Monograph, 9. American Society of Agronomy, Madison WI pp. $425-442$.

Monreal, C.M., Schnitzer, M., Schulten, H.R., Camppbell, C.A., Anderson, D.W., 1995. Soil organic structures in macro and microaggregates of a cultivated brown chernozem. Soil Biology and Biochemistry 27, 845-853.

Peterson, G.A., Westfall, D.G., Cole, C.V., 1993. Agroecosystem approach to soil and crop management research. Soil Science Society of America Journal 57, 1354-1360.

Peterson, G.A., Westfall, D.G., Peairs, F.B., Sherrod, L., Poss, D., Gangloff, W., Larson, K., Thompson, D.L., Ahuja, L.R., Koch, M.D., Walker, C.B., 1999. Sustainable dryland agroecosystem management. Technical Bulletin TB99-1. Department of Soil and Crop Sciences, Colorado State University, Fort Collins CO.

Peterson, G.A., Westfall, D.G., Hansen, N.C., 2012. Enhancing precipitation use efficiency in the world's dryland agroecosystems. In: Lal, R., Stewart, B.A. (Eds.), Adv. in Soil Sci. - Soil Water and Agronomic Productivity. CRC Press, Boca Raton, FL, pp. 455-476.

Philip, J.R., 1957. The theory of infiltration. 4. Sorptivity and algebraic infiltration equations. Soil Science 84, 257-264.

Rhoton, F.E., Shipitalo, M.J., Lindbo, D.L., 2002. Runoff and soil loss from Midwestern and southeastern US silt loam soils as affected by tillage practice and soil organic matter content. Soil and Tillage Research 66, 1-11.

SAS Institute, 2011. SAS user's guide. SAS Inst., Cary, NC, USA.

Shaver, T.M., Peterson, G.A., Ahuja, L.R., Westfall, D.G., Sherrod, L.A., Dunn, G., 2002. Surface soil physical properties after 12 years of dryland no-till management Soil Science Society of America Journal 66, 1296-1303.

Shaver, T.M., Peterson, G.A., Sherrod, L.A., 2003. Cropping intensification in dryland systems improves soil physical properties: regression relations. Geoderma 116, 149-164.

Sherrod, L.A., Dunn, G., Peterson, G.A., Kolberg, R.L., 2002. Total Inorganic carbon analysis by modified pressure-calcimeter method. Soil Science Society of America Journal 66 299-305.

Smith, R.E., 1999. Rapid measurement of soil sorptivity. Soil Science Society of America Journal 63, 55-57.

Taylor, S.A., Ashcroft, G.L., 1972. Physical Edaphology. Freeman, San Francisco.

Unger, P.W., Payne, W.A., Peterson, G.A., 2006. Water conservation and efficient use, In: Peterson, G.A., Unger, P.W., Payne, W.A. (Eds.), Dryland Agriculture, 2nd edition. ASA-CSSA-SSSA, Madison, WI, pp. 39-85. 